Two main courses are provided, 'technical' and 'craft', each of not less than five years duration. All trainees spend their first year on preliminary courses in the Centre to find the direction in which their abilities lie, and to give them an insight into the fundamentals of engineering with particular reference to those branches with which the Birlec Co. is concerned. After this probationary period, training is then continued in appropriate departments for the remainder of the five-year period, selected apprentices returning to the Centre for advanced instruction at an intermediate stage. All trainees are also required to attend suitable courses at local technical colleges for at least one day a week. Selected apprentices may be offered the opportunity of attending sandwich courses of four to five years at a college of technology, leading to qualification for membership of the appropriate professional engineering institution. There are at present about sixty apprentices in the firm, some forty of whom were recruited this year.

\section{Swiss Society for Natural Sciences}

The 136th annual meeting of the Swiss Society for Natural Sciences will be held during September 22-24. at Basle. The opening address by the president, Prof. A. Werthemann of Basle, is on "Pathology of Embryonic Development". Dr. A. Wettstein of Basle will speak on "Aldosteron and Other Suprarenal Hormones", Prof. J. Piveteau of the Sorbonne on "Recent Progress in Human Palæontology in France", and Prof. E. Hadorn of Zurich on "Hereditary Constitution and the Formation of Characteristics". At a joint symposium, the Societies for Medical Biology and for Genetics will discuss "Malformation of the Gonads and Genetic Sex". The Society for the History of Medicine and Science will hold a symposium on "Medicine at Basle in the Baroque Period". A public session of the Swiss Community for Educational and Scientific Research Films will be addressed by Dr. G. Wolf, of Göttingen, and biological and medical films will be shown.

The meeting will be held in fifteen main sections. Foreign contributors include C. E. Tilley (Mineralogy and Petrography) and P. Tschumi (Zoology and Entomology) of Cambridge, and several from the East European Universities of Poznan (Anthropology), Budapest and Greifswald (Chemistry). In the Geophysical, Meteorological and Astronomical Section, Prof. J. Lugeon of Zurich will report on "The World Comparison of Radiosondes at Payern", and on "Measurements of the Electric Potential Gradient and the Conductivity of the Air by Radiosondes", and J. Hëfelin and R. Lotmar of Zurich on the "Determination of Weather Effects on Skin Permeability (Experiments on Rabbits)". Prof. H. Hadwiger of Bern speaks in the Mathematical Section on "Selected Problems of Combinatory Geometry in Euclidian and Spherical Space". The Section for Logic and Philosophy lists four prominent speakers, Profs. Paul Bernays of Zurich ("From Syntax to Philosophy of Science"), Emil Walther of Zurich ("The Problem of Direct, Phenomenological Thought"), Felix Fiala of Neuchâtel ("Methodological Notes on Formalism") and François Bonnet of Geneva ("Irreversibility, Disorder and Chance"). The Society announces as the new topic for the one thousand francs Schläfli Prize (open only to candidates of Swiss nationality, closing date April 1, 1959): "Researches on the Distribution of Polyploid Plant Species in Switzerland".

\section{Zoological Nomenclature}

As from January 20, 1957, the International Commission on Zoological Nomenclature will start voting on the following cases involving the possible use of its plenary powers for the purposes specified against each case, full details of which have already been published (Bull. Zool. Nom., 12, Pts. 4 and 5; July 20, 1956) : (1) depurator Linnaeus, 1758 (Cancer), interpretation of, by neotype designated for (cl. Crustacea, order Decapoda) ; (2) Cherax (emend. of Cheraps) Erichson, 1846, and Palinurus (emend. of Pallinurus) Weber, 1795, validation (cl. Crustacea, order Decapoda); (3) ferox Gmelin, 1771 (Accipiter), suppression (cl. Aves); (4) Maja Lamarck, 1801, validation of and designation of type species for (cl. Crustacea, order Decapoda) ; (5) Sao Barrande, 1846, and Ellipsocephalus (emend. of Elleipsocephatus) Zenker, 1833, validation (cl. Crustacea, order Stomatopoda); (6) Heteralocha Cabanis, [1851], validation (cl. Aves); (7) Acrodytes Fitzinger, 1843, venulosa Laurenti, 1768 (Rana) and tibiatrix Laurenti, 1768 (Hyla), suppression (cl. Amphibia, order Salientia); (8) Palaeophonus (emend. of Palaeophoneus) Lindström and Thorell, 1884, validation (cl. Arachnida); (9) Actinocrinus gilbertsoni Phillips, 1836, interpretation of, by neotype (cl. Crinoidea). Comments should be sent as soon as possible to the secretary to the Commission, Francis Hemming, 28 Park Village East, Regent's Park, London, N.W.1.

\section{Museum of Applied Science of Victoria, Melbourne : Report for $1954-55$}

THE annual report of the Museum of Applied Science of Victoria, Melbourne, for the year ended June 30,1955 (pp. $17 ; 1956$ ), records major steps in the general building programme which should go a long way to ease congestion. A special exhibit of a demonstration model of the Lurgi plant for the production of gas from the extensive brown-coal deposits in the Latrobe valley has been installed in the main entrance to the Museum. This semi-diagrammatic model was constructed by the staff of the Museum and shows each unit in section, starting with the high-pressure reaction unit and proceeding to the final gas-purification tower from which it will be piped to Melbourne. Each stage of the process is explained by a panel of text, which is illuminated in sequence by an automatic time-switch.

\section{Extension to the Rowett Research Institute}

Throvar the generosity of the Wellcome Trust, the Rowett Research Institute, Aberdeen, is now able to go ahead with the erection of a building to house the special equipment for research in animal nutrition which the Rockefeller Foundation was prepared to grant to the Institute if a suitable building were put up for it. These awards by the Wellcome Trust and the Rockefeller Foundation-up to $£ 5,000$ and $£ 4,900$ respectively-will now permit the staff of the Institute to isolate and prepare, in larger quantities than can at present be achieved in its laboratories, microbial, plant and animal constituents for further identification, analysis and in vivo testing.

\section{The Library Association}

THE annual conference of the Library Association will be held at Folkestone during September 18-21, under the presidency of Mr. Edward Sydney. The programme includes papers on international librarianship (Dr. H. Coblans, head of the Information Service 